\title{
Pelatihan Penggunaan Google Classroom sebagai Media Pembelajaran Daring pada Guru-Guru SD Negeri 091316 Kabupaten Simalungun
}

\author{
Osco Parmonangan Sijabat ${ }^{1}$, Lisbet Novianti Sihombing ${ }^{2}$, Nurliani Siregar ${ }^{3}$, Herlina \\ Hotmadinar Sianipar ${ }^{4}$, Rianita Simamora ${ }^{5}$, David Berthony Manalu6, Apriani Sijabat ${ }^{7}$, \\ Natalina Purba ${ }^{8}$, Rudiarman Purba ${ }^{9}$, Susy Alestriani Sibagariang 10 \\ 1,2,3,4,5 Universitas HKBP Nommensen \\ 6,7,8,9,10 Universitas HKBP Nommensen Pematangsiantar \\ * Email korespondensi: oscosijabat@uhn.ac.id, (081370831631)
}

Received: 30 Desember 2020; Revision: 10 Februari 2021; Accepted: 30 Maret 2021

\begin{abstract}
Abstrak
Multimedia sangat dibutuhkan dalam proses pembelajaran khususnya bagi guru. Peran gurumerupakan kunci utama dalam pengelolaan proses pembelajaran dikelas. Pelatihan ini bertujuan untuk mempermudah para guru untuk melaksanakan pembelajaran daring. Metode kegiatan yang digunakan dalam pelatihan pada kegiatan ini meliputi ceramah bervariasi dan latihan atau praktek. Hasil pelatihan yang akan dicapai berupa persepsi guru menjadi lebih leluasa memilih model, metode, maupun media yang di terapkan di masa pembelajaran daring melalui media pembelajaran online google classroom. Sebelum diberikan pelatihan, guru-guru SD Negeri 091316 Kabupaten Simalungun 100\% belum pernah mengunakan media pembelajaran online google classroom, namun setelah pelatihan pembelajaran daring yang diberikan, para guru merasa bahwa dengan menggunakan media pembelajaran online google classroom dapat mempermudah proses penyampaian materi dalam proses pembelajaran. Hasilnya seluruh guru-guru SD Negeri 091316 Kabupaten Simalungun setuju bahwa Google Classroom memuaskan dalam penggunaannya guna mendukung proses berjalannya pembelajaran daring.
\end{abstract}

Kata Kunci : Pelatihan; Pembelajaran Daring; Google Classroom.

Sijabat, O., Sihombing, L., Siregar, N., Sianipar, H., Simamora, R., Manalu, D., Sijabat, A., Purba, N., Purba, R., \& Sibagariang, S. (2021). Pelatihan Penggunaan Google Classroom sebagai Media Pembelajaran Daring pada Guru-Guru SD Negeri 091316 Kabupaten Simalungun. Masyarakat Berdaya dan Inovasi, 2(1). doi:https://doi.org/10.33292/mayadani.v2i1.49

This is an open access article under the $\underline{\mathrm{CC}-\mathrm{BY}-\mathrm{SA}}$ license.

\section{PENDAHULUAN}

Proses pembelajaran merupakan proses berkelanjutan yang membutuhkan singkronisasi dari lembaga pemerintah, sekolah dan tenaga pendidik. Peran pendidik merupakan kunci utama dalam pengelolaan proses pembelajaran dikelas. Pendidik mampu memberikan inovasi dan kreativitas pembelajaran yang baik manakala mampu memahami hakikat akan proses pembelajaran sesungguhnya. Demi mewujudkan hal tersebut tentu salah satu upaya yang dilakukan pemerintah dengan membentuk forum musyawarah guru mata pelajaran (MGMP) di setiap kabupaten baik

https://doi.org/10.30874/MAYADANI.v1i1.00001

info@mayadani.org 
ditingkat sekolah dasar sampai dengan sekolah menengah. Melalui program ini diharapkan mampu menjadi wadah bagi para guru mata pelajaran untuk bertukar informasi tentang kebijakan dan program program terbaru yang diterapkan olehpemerintah. Hal tersebut tentu mengharuskan para guru-guru mata pelajaran untuk belajar kembali bagaimana membuat penelitian tindakan kelas yang efektif berbasis pada kurikulum 2013. Selain itu minat guru dalam pembuatan penelitian tindakan kelas sangat rendah yang disebabkan oleh pemahaman para guru guru tentang kesulitan dalam pembuatan penelitian tindakan kelas. Tentu permasalahan ini harus diselesaikan melalui tindakan secara tepat yakni melalui pelatihan pembuatan penelitian tindakan kelas yang efektif dan inovatif berbasis pendekatan saintifik pada kurikulum 2013.

Google Classroom (Ruang Kelas Google) adalah suatu serambi aplikasi pembelajaran campuran secara online yang dapat digunakan secara gratis. Pendidik bisa membuat kelas mereka sendiri dan membagikan kode kelas tersebut atau mengundang para siswanya. Google Classroom ini diperuntukkan untuk membantu semua ruang lingkup pendidikan yang membantu siswa untuk menemukan atau mengatasi kesulitan pembelajaran, membagikan pelajaran dan membuat tugas tanpa harus hadir ke kelas. Google Classroom merupakan aplikasi berbasis E-learning, penyampaian pembelajaran dengan e-learning merupakan pembelajaran dengan memanfaatkan teknologi internet untuk meningkatkan lingkungan belajar dengan konten yang kaya dengan cakupan yang luas. Elearning merupakan pemanfaatan media pembelajaran menggunakan internet, untuk mengirimkan serangkaian solusi yang dapat meningkatkan pengetahuan dan keterampilan. Setiap metode pembelajaran harus mengandung rumusan pengorganisasian bahan pelajaran, strategi penyampaian, dan pengelolaan kegiatan dengan memperhatikan faktor tujuan belajar, hambatan belajar, karakteristik peserta didik, agar dapat diperoleh efektivitas, efisiensi, dan daya tarik pembelajaran (Miarso, 2004).

Media pembelajaran adalah segala sesuatu yang menyangkut software dan hardware yang dapat digunakan untuk menyampaikan isi materi ajar dari sumber belajar ke perorangan maupun kelompok (Tamba, 2012). Adapun fungsi pembelajaran menurut Sudrajat (Fitra dan Lestari, 2017) yaitu : a). media pembelajaran dapat mengatasi keterbatasan pengalaman (dapat dilakukan secara visual) oleh para mahasiswa, b).media pembelajaran dapat melampaui batasan ruang kelas, c). media pembelajaran memungkinkan adanya interaksi langsung antara mahasiswa dengan lingkunganya, d). media membangkitkan motivasi untuk belajar komunikasi daring. Komunikasi Daring adalah cara berkomunikasi di mana penyampaian dan penerimaan pesan dilakukan dengan atau melalui jaringan Internet. Terdapat 2 jenis komunikasi daring yaitu: 1). komunikasi daring sinkron (serempak) Komunikasi daring serempak atau komunikasi daring sinkronadalah komunikasi menggunakan komputer sebagai media, yang terjadi secara serempak, waktu nyata (real time). Contoh komunikasi sinkron adalah Text chat. Text chat adalah sebuah fitur, aplikasi, atau programdalam jaringan Internet untuk berkomunikasi dan bersosialisasi langsung sesama pemakai Internet Video chat: Video chat merupakan teknologi untuk melakukan interaksi audio dan video secara realtime antara pengguna di lokasi yang berbeda. Video chatting biasanya dilakukan melalui perangkatkomputer maupun tablet atau smartphone (juga disebut telepon video call), 2). Komunikasi daring asinkron (tak serempak) Komunikasi daring tak serempak atau asinkron adalah komunikasi menggunakan perangkat komputer dan dilakukan secara tunda. Contoh komunikasi daring asinkron adalah e-mail, forum, rekaman simulasi visual, serta membaca dan menulis dokumen daring melalui World Wide Web. Pembuatan kelas terdiri dari kelas "perkembangan peserta didik". Diawali dari membuka situs classroom.google.com pada brower dengan login account. 


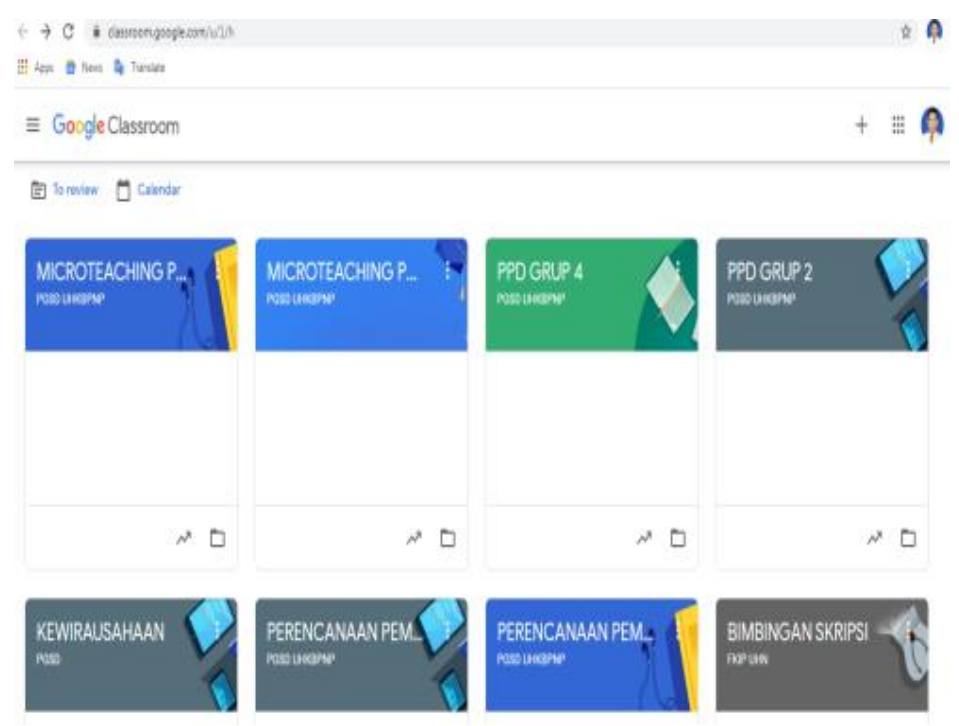

Gambar 1: login akun

Langkah selanjutnya adalah membuat kelas dilanjutkan dengan membagikan kode kelas kepada peserta. Pada tahapan ini sekaligus pengguna melakukan uji coba media dan menggunakan sebagai pembelajaran daring.

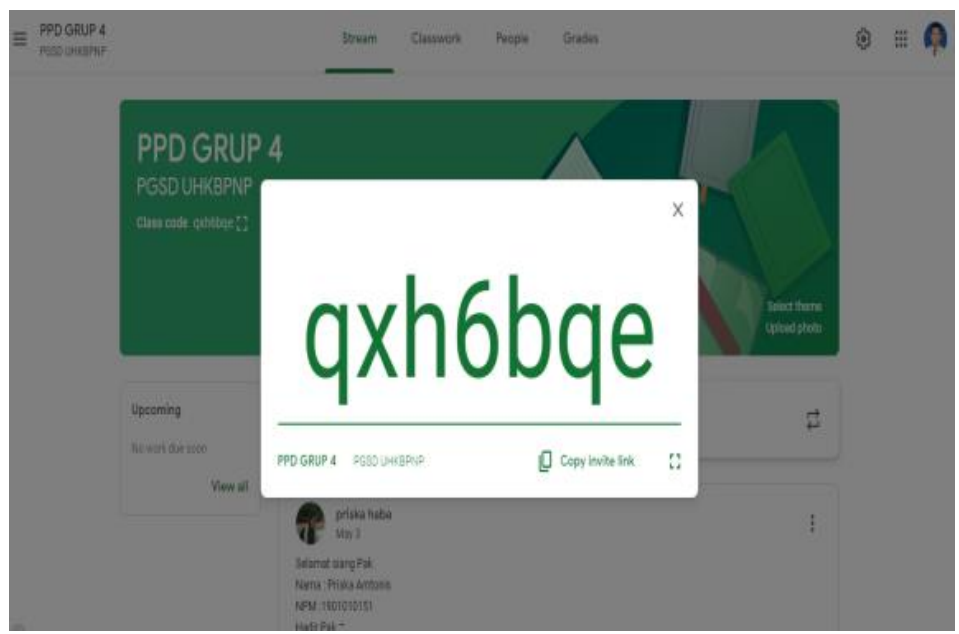

Gambar 2: membuat kelas dan pembagian kode kelas

Setelah kode kelas dibagikan tahapan selanjutnya adalah peserta melihat materi (file \& video) pada forum dilanjutkan dengan pengerjaan tugas. Video pembelajaran pada kelas dibuat dengan menggunakan Camtasia Record, dosen memberikan penjelasan materi dalam bentuk video dan dibagikan kepada mahasiswa. Dengan pembelajaran berbasis video mahasiswa dapat melihat penjelasan dosen sehingga lebih mudah dalam menyimak materi tanpa harus bertemu maupun live pada waktu tertentu. 


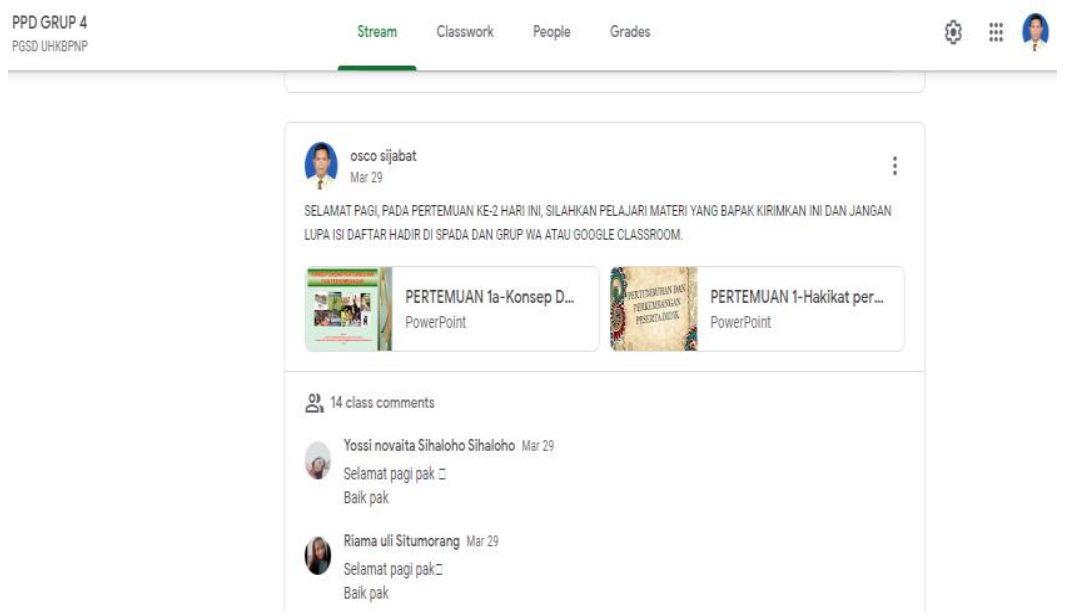

Gambar 3: materi dan video pembelajaran pada classroom

Selain melihat materi dan komentar pada forum mahasiswa diwajibkan untuk mengerjakan tugas yangada pada tugas kelas. Tugas tersebut dapat sekaligus dikoreksi oleh dosen dan diberikan penilaian. Adapun mitra dalam pelaksanaan kegiatan pengabdian ini adalah guru-guru SD Negeri 091316 Kabupaten Simalungun. Melihat dari uraian sebelumnya hal tersebut juga dialami oleh mitra dan menjadi salah satu permasalahan mitra saat ini. Inilah yang seharusnya menjadikan para guru-guru haruslah memiliki inovasi dalam setiap proses pembelajaran sehingga akan terbentuk kultur budaya yang sistematis dalam setiap proses pembelajaran melalui penelitian tindakan kelas yang dilakukan para guru-guru. Program kegiatan ini secara umum bertujuan memberikan pelatihan pembelajaran daring yang bermutu dengan memanfaatkan multimedia berupa google classsroom secara efektif dalam pembelajaran. Adapun permasalahan dalam kegiatan ini lebih pada persepsi guru-guru SD Negeri 091316 Kabupaten Simalungun mengenai pembelajaran daring dan tingkat pemahaman serta keterampilan guru mengenai pembelajaran daring dengan mengggunakan google classsroom.

\section{METODE}

Metode kegiatan yang digunakan dalam pelatihan pada kegiatan ini meliputi 2 (dua) metode yaitu ceramah bervariasi dan latihan atau praktek. Ceramah digunakan oleh tim pengabdi untuk menyampaikan materi berupa pembelajaran daring di new normal covid 19 melalui media google classroom,evaluasi pembelajaran daring, dan implementasi pembelajaran daring. Ceramah didukung pemanfaatan ICT dengan bantuan laptop dan LCD untuk menayangkan materi pengabdian dalam waktu terbatas yang telah di jadwalkan. Dalam pelatihan atau praktik ini peserta akan mempraktikan secara optimal dan mendalam cara penerapan pembelajaran daring sesuai saran yang diberikan oleh tim pengabdi. Peserta akan diberi tugas mandiri yang dikerjakan secara individu yang akan di bimbing oleh masing masing dosen tim pengabdi. Dalam prosesnya guru diminta mengisi kuesioner yang diisikan sebelum dan sesudah pelatihan. Untuk melihat persepsi guru digunakan materi terkait dengan pemahaman guru dalam pembelajaran daring di new normal covid 19 melalui media google classroom, sedangkan untuk melihat tingkat pemahaman serta keterampilan guru-guru sebelum dan setelah pembelajaran daring digunakan materi media pembelajaran daring, evaluasi pembelajaran daring dan implementasi pembelajaran daring.

Pelaksanaan Pengabdian Kepada Masyarakat berlangsung pada hari Rabu-Kamis, tanggal 2425 Maret 2021 yang dimulai pada jam 7.30 Wib sampai selesai. Dengan dihadiri 30 orang peserta yaitu Guru-Guru SD Negeri 091316 Kabupaten Simalungun dengan tempat pelaksanaan di Kantor aula SD Negeri 091316 Kabupaten Simalungun. Adapun yang menjadi narasumber dalam kegiatan ini adalah Para Dosen di Program Studi Pendidikan Ekonomi antara lain: 1).Osco Parmonangan Sijabat, S.Pd., M.Pd., 2).Lisbet Novianti Sihombing, S.Pd., M.Pd., 3).Dra. Herlina Hotmadinar Sianipar, M.Si., 4).Susy Alestriani Sibagariang, S.Pd., M.M., Dosen Program Studi Pendidikan Agama Kristen (PAK) yaitu: 
1).Pdt. Dr. Nurliani Siregar, M.Pd., Dosen Pendidikan Matematika yaitu: 1). Rianita Simamora S.Pd., M.Pd., Dosen Program Studi Pendidikan Guru Sekolah Dasar (PGSD) yaitu: 1). Dr. Natalina Purba, M.Pd., Dosen Program Studi Pendidikan Bahasa Inggris yaitu: 1). David Berthony Manalu, S.Pd., M.Pd., 2). Rudiarman Purba, S.Pd., M.Pd., dan Dosen Program Studi Pendidikan Fisika yaitu: 1). Apriani Sijabat, S.Si., M.Pd., selaku Tim Pengabdi. Agenda kegiatan pengabdian di Kantor aula SD Negeri 091316 Kabupaten Simalungun dilakukan pemaparan materi dengan narasumber yang merupakan tim pengabdi yang berjumlah 9 (sembilan) orang. Penyampaian materi dari tim pengabdi, antara lain: Pembelajaran daring di new normal covid 19, Media Pembelajaran google classroom, Implementasi Pembelajaran hybrid (campuran antara daring dan tatap muka), serta Evaluasi Pembelajaran Daring. Setelah penyampaian materi kemudian dilanjutkan dengan praktek menggunakan media yang telah disampaikan pada materi dan sesi tanya jawab mengenai berbagai kendala yang dihadapi guru pada pembelajaran daring.

Kegiatan pengabdian dilanjutkan dengan pemberian tugas individu pada para guru-guru SD Negeri 091316 Kabupaten Simalungun untuk menyusun bahan ajar, dan evaluasi pembelajaran menggunakan media pembelajaran daring sesuai dengan materi yang telah disampaikan oleh narasumber. Tugas individu bagi guru-guru SD Negeri 091316 Kabupaten Simalungun tersebut akan dikumpulkan secara online melalui link yang telah disediakan untuk pengumpulan tugas. Pelatihan dilakukan oleh tim pengabdi dengan harapan semakin banyak guru-guru SD Negeri 091316 Kabupaten Simalungun yang dapat melaksanakan pembelajaran daring dengan media yang mengefisienkan proses pembelajaran daring.

\section{HASIL DAN PEMBAHASAN}

Sebelum dilakukan pelatihan tentang Pembelajaran daring di new normal covid 19, Media Pembelajaran google classroom, Implementasi Pembelajaran hybrid (campuran antara daring dan tatap muka), persepsi guru mengenai pembelajaran daring masih sedang-sedang saja, persentase penerapan model pembelajaran daring 50\% sudah menerapkan sedangkan 50\% kadang- kadang $0 \%$ yang belum menerapkan.

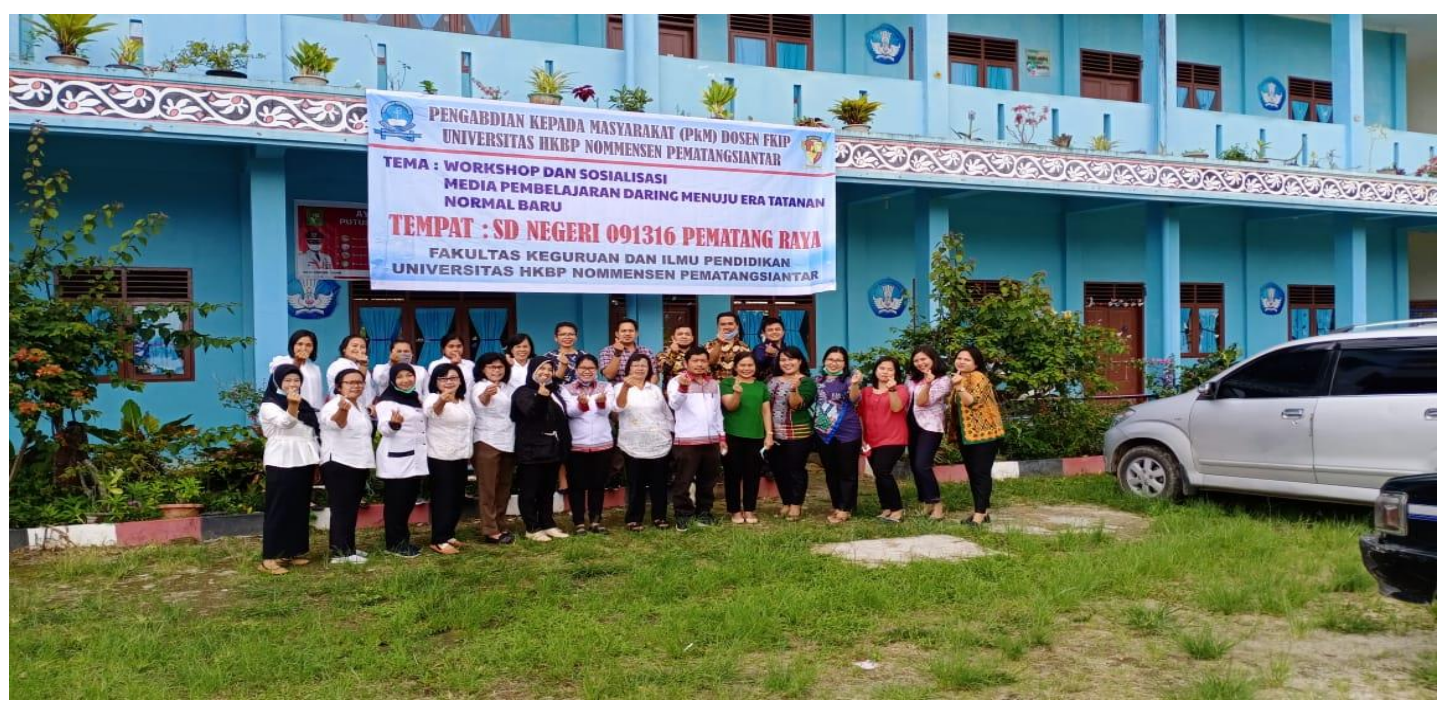

Gambar 1: Foto Bersama Para Guru Sebelum Acara Sosialisasi dan Pelatihan Dilaksanakan 
Masyarakat Berdaya dan Inovasi, 2 (1), 2021

Osco Parmonangan Sijabat, Lisbet Novianti Sihombing, Nurliani Siregar, Herlina Hotmadinar Sianipar, Rianita Simamora, David Berthony Manalu, Apriani Sijabat, Natalina Purba, Rudiarman Purba, Susy Alestriani Sibagariang

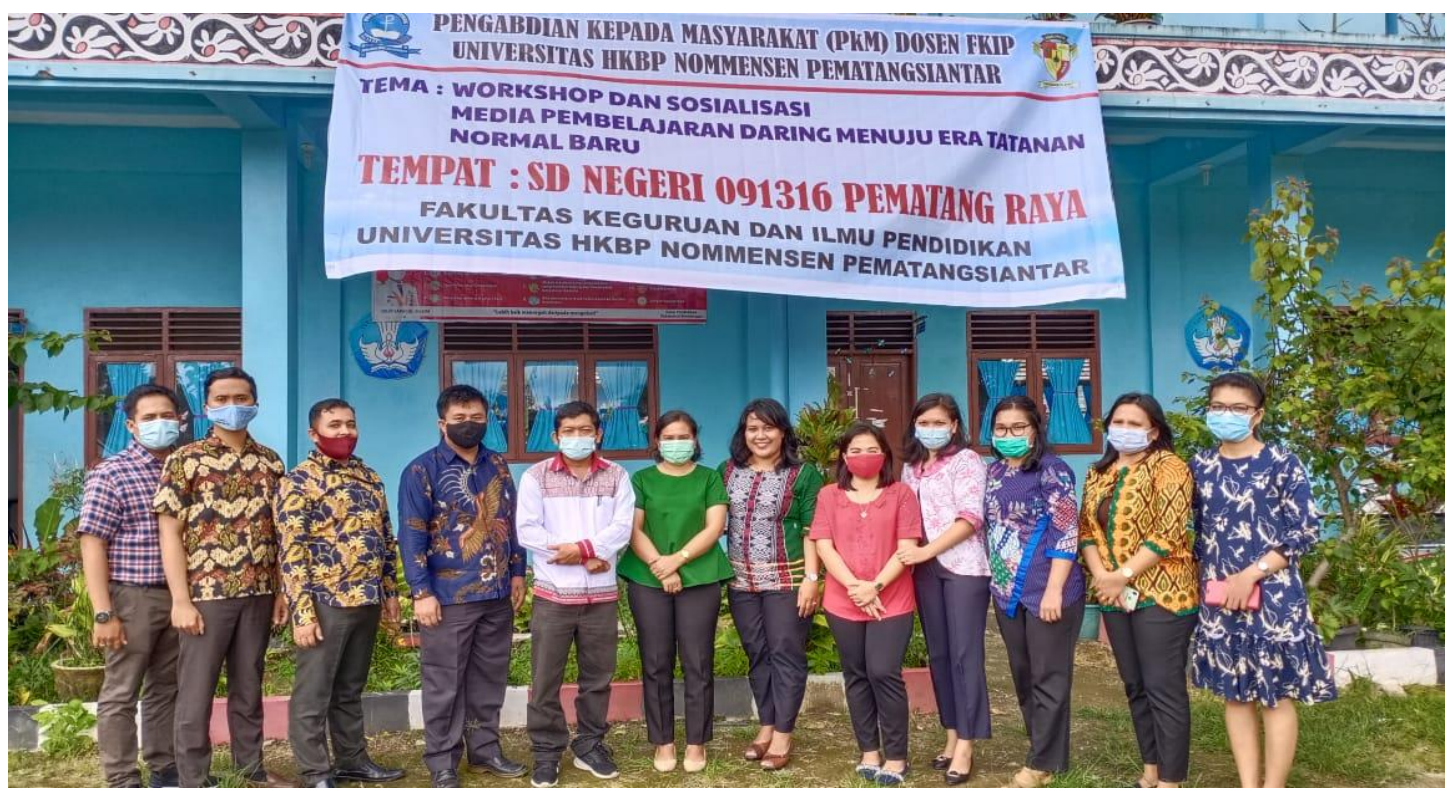

Gambar 2: Foto Para Dosen Tim Pengabdi Dalam Pelatihan Pembelajaran Daring

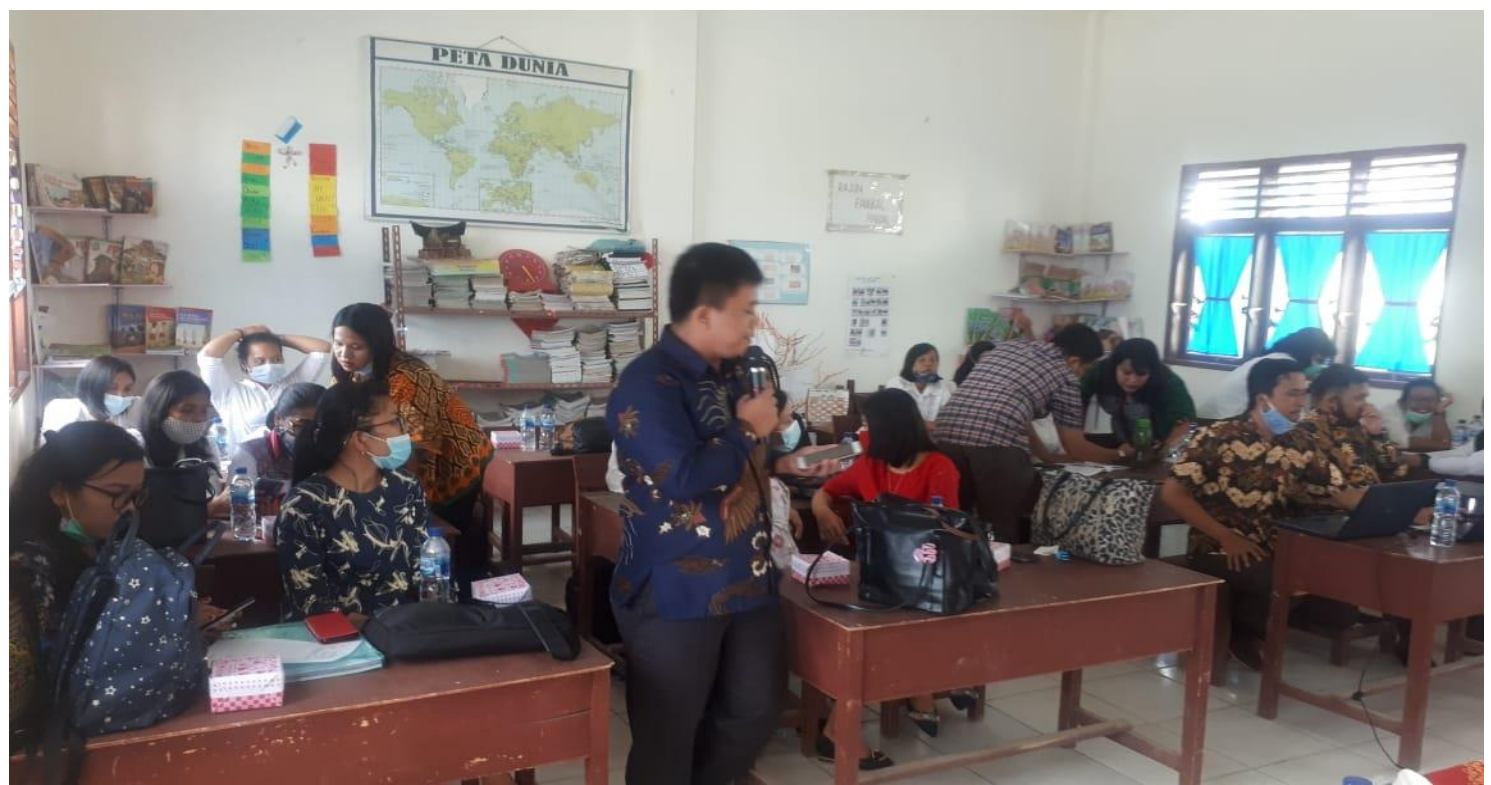

Gambar 3: Peserta Mendengarkan Penyuluhan Pembelajaran Daring Menggunakan Google Classroom 


\section{Osco Parmonangan Sijabat, Lisbet Novianti Sihombing, Nurliani Siregar, Herlina Hotmadinar Sianipar, Rianita Simamora, David Berthony Manalu, Apriani Sijabat, Natalina Purba, Rudiarman Purba, Susy Alestriani Sibagariang}

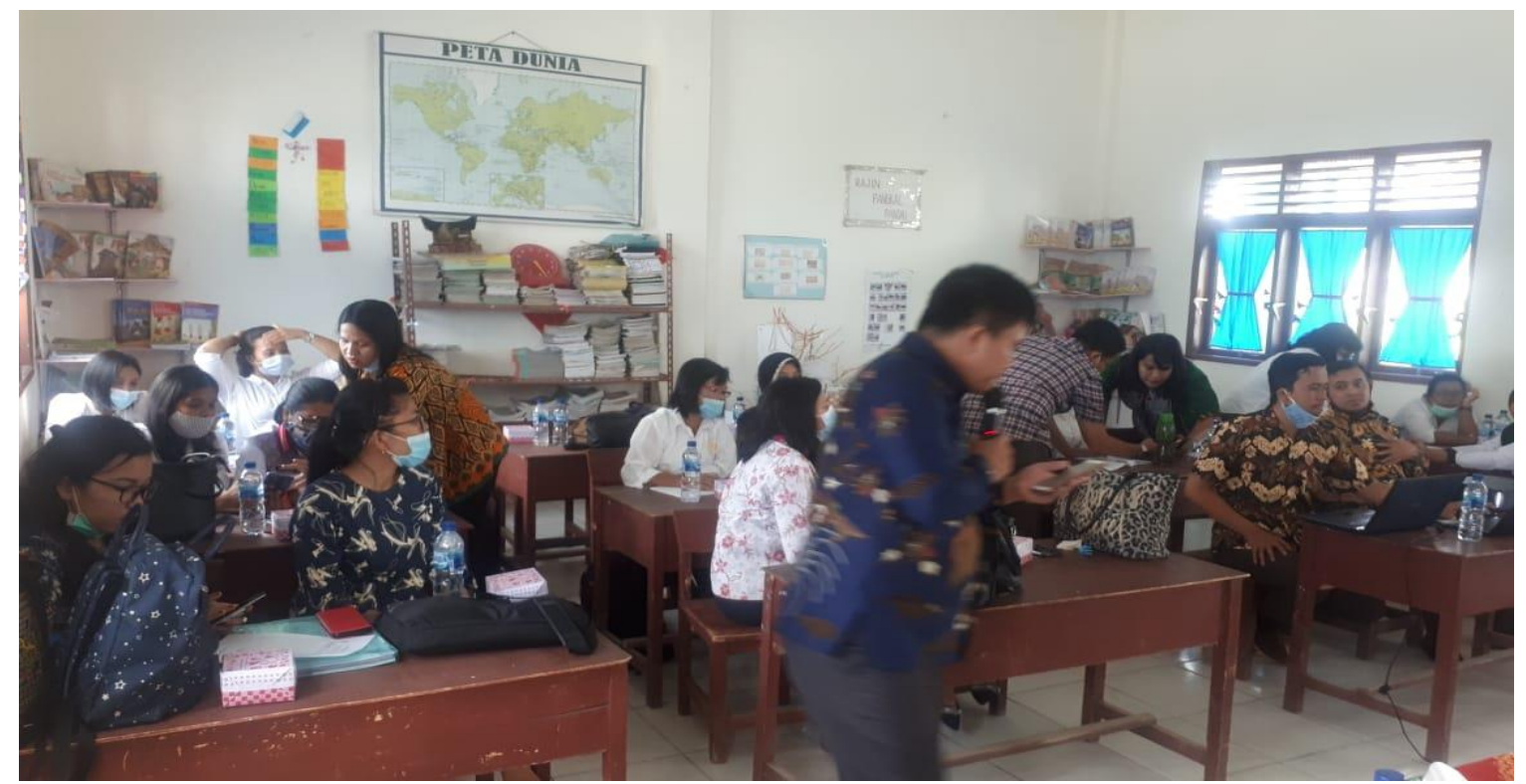

Gambar 4: Tim Pengabdi Memberikan Praktek Pembelajaran Daring Menggunakan Google Classroom

Setelah diberikan materi dan pandangan mengenai pembelajaran daring persepsi guru menjadi lebih leluasa memilih model, metode, maupun media yang di terapkan untuk pembelajaran daring di masa sekarang. Persentase perilaku siswa belajar yang menonjol pada pembelajaran daring yaitu $62 \%$ proses belajar hanya bergantung pada mesin pencari, $25 \%$ menyerap ilmu pengetahuan hasil Informasi dari guru, dan $13 \%$ menjawab. Persentase karakteristik guru pada pembelajaran daring yaitu $63 \%$ kreatif dan inovatif dan mengembangkan metode belajar dan $38 \%$ peran penting guru sebagai fasilitator, motivator, dan inspiratory, persentasi Peranan TIK sebagai media jarak jauh pada proses pembelajaran daring yaitu $50 \%$ Peningkatan mutu, relevansi, dan daya saing pengkatan kualitas pendidikan, $37 \%$ Penguat tata kelola karena adanya peranan TIK dalam pembelajaran dan $13 \%$ menjawab Penyelenggaraan pendidikan yang begitu murah dan terjangkau pembelajaran terasa sangat terjangkau, persentase penerapan model pembelajaran kontruktivistik yaitu $100 \%$ guru menjawab berfikir Kritis, sebagian guru menjawab bahwa peningkatan teknologi digital mengkondisikan pembelajaran yang nyata bagi siswa pembelajaran digital dipandang guru dapat mengkondisikan kelas secara online hingga proses pembelajaran dapat lebih kondusif, persentase penyesuaian karekteristik Guru yaitu $75 \%$ Sebagai fasilitator, motivator, dan isnfirator, 13\% Sebagai pendidik, Pengajar, dan penasehat, $12 \%$ lainya menjawab Sebagai pelatih, Pembimbing, dan pengawas, persentase karakter guru yaitu $87 \%$ menjawab kreatif dan iovatif dalam mengembangkan metode belajar dan $13 \%$ menjawab peran penting guru sebagai fasilitator, motivator, dan inspiratory, persentase tahapan kompetensi e-learning guru menjawab 43\% 2-1-4-3, $29 \%$ 1-2-3-4, $14 \%$ 1-3- 4-2, dan 14 lainnya menjawab 2-3-1-4, persentase keterampilan siswa yang mampu Sharing yaitu $57 \%$ kecakapan kreatif dan inovatif, $29 \%$ kecakapan kepemimpinan produktif dan bertanggung jawab, dan $14 \%$ lainya menjawab Kecakapan sosial, dan persentase manfaat media yang melimpah untuk siswa yaitu $86 \%$ menjawab belajar secara mandiri dan $14 \%$ lainnya menjawab saling chatingan bersama teman-teman.

\section{Tingkat Pemahaman Serta Keterampilan Guru Mengenai Pembelajaran Daring Sebelum Diberikan Pelatihan.}

a. Sebelum dilaksanakannya kegiatan pelatihan guru telah menjawab beberapa angket yang diberikan kepada para guru yang mengikuti kegiatan tersebut diketahui bahwa guru-guru SD Negeri 091316 Kabupaten Simalungun $100 \%$ belum pernah mengunakan media pembelajaran google classsroom 
sehingga mereka juga tidak akan tahu kesulitan, tingkat keberhasilan, dan cara menyampaikan materi tersebut kepada siswanya.

b. Proses evaluasi pembelajaran daring sebelum diadakan pelatihan, peserta PKM $100 \%$ sudah menerapkan pembelajaran daring dalam kegiatan belajar mengajar sehari- hari. Dalam proses evaluasi pembelajaran daring, para peserta ada yang sudah pernah dan ada juga yang tidak pernah menggunakan aplikasi google form dan quiz. Lebih dari rata-rata peserta PKM yang mengalami kesulitan dalam menggunakan aplikasi google form dan quiz. Terdapat 17 orang yang mengatakan "ya", dan 13 orang yang mengatakan "tidak".

c. Sebelum Pelatihan dari, para peserta daring yaitu guru-guru SD Negeri 091316 Kabupaten Simalungun telah mengisi angket implementasi pembelajaran daring. Dalam hal ini sebelum diberikan pelatihan bapak/ibu guru lebih dari rata-rata pernah menggunakan google classroom. Namun hanya 12 peserta yang secara penuh mengimplementasikan pembelajaran daring menggunakan aplikasi google classroom. Dalam melakukan pembelajaran daring, hampir 100\% peserta menggunakan aplikasi Whatsapp dalam mengimplementasikan pembelajaran dari dalam sehari-hari. Dalam proses mengajar peserta PKM mengakui bahwa mengunakan aplikasi google classroom itu mudah karena dari menjawab $100 \%$ peserta menjawab mudah. Dalam berlangsungnya implementasi pembelajaran daring, bagi peserta PKM, tampilan Google Classroom sangat mudah dan jelas untuk dipahami dan pengunaan aplikasi google classroom mempermudah peserta memperoleh informasi mengenai tugas siswa dengan realtime. Hal ini dilihat bahwa lebih dari ratarata yang menjawab "ya".

\section{Tingkat Pemahaman Serta keterampilan guru-guru SD Negeri 091316 Kabupaten Simalungun aya Mengenai Pembelajaran Daring Setelah Diberikan Pelatihan.}

a. Setelah pelatihan pembelajaran daring yang diberikan, para guru-guru SD Negeri 091316 Kabupaten Simalungun merasa bahwa dengan menggunakan google classsroom dapat mempermudah proses penyampaian materi dalam proses pembelajaran daring. Setelah pelatihan pembelajaran daring yang diberikan, para guru-guru SD Negeri 091316 Kabupaten Simalungun tidak mengalami kesulitan dalam belajar dan mempraktekan menggunakan google classroom. Dengan menggunakan media google classroom dalam proses belajar dan mengajar daring cukup mempengaruhi keaktifan siswa dalam belajar dan juga mempengaruhi hasil belajar siswa dalam pembelajaran daring.

b. Setelah mendapatkan pelatihan pembelajaran daring, seluruh guru-guru SD Negeri 091316 Kabupaten Simalungun diharapkan dapat menggunakan media yang efektif dalam proses pembelajaran daring, baik penyampaian materi hingga kepada evalusasi pembelajaran. Pada pelatihan pembelajaran daring ini juga terdapat materi evaluasi pembelajaran daring yang disertai dengan praktek langsung. Seluruh guru-guru SD Negeri 091316 Kabupaten Simalungun yang mengikuti pelatihan menyetujui bahwa dengan menggunakan Google Form dan Quiz dapat mempermudah para guru untuk melaksanakan evaluasi pembelajaran daring. Sebagian besar guruguru SD Negeri 091316 Kabupaten Simalungun yang mengikuti pelatihan merasa tidak kesulitan dalam mempelajari Google Form dan Quiz sebagai media evaluasi pembelajaran daring. Setelah pelatihan pembelajaran daring berlangsung, para guru termotivasi untuk melaksanakan evaluasi pembelajaran daring yang lebih bervariasi. Para guru dapat memilih media evaluasi pembelajaran daring yang paling sesuai dengan karakteristik peserta didik pada masing-masing sekolah.

c. Setelah menerima pelatihan pembelajaran daring tentang media-media yang dapat membantu proses pembelajaran daring menjadi efektif. Para guru-guru SD Negeri 091316 Kabupaten Simalungun Sangat setuju bahwa penggunaan Google Classroom sangat berguna untuk proses pembelajaran 
daring. Para guru-guru SD Negeri 091316 Kabupaten Simalungun menyetujui bahwa Goggle Classroom membantu pekerjaan menjadi lebih efektif. Google Classroom membuat para guru menjadi lebih produktif dalam proses pembelajaran daring yang sedang berlangsung saat ini. Setelah mendapatkan pelatihan pembelajaran daring, sebagian besar guru-guru SD Negeri 091316 Kabupaten Simalungun setuju bahwa dengan menggunakan Goggle Classroom sebagai ruang kelas virtual dalam proses pembelajaran daring dapat lebih menghemat waktu.

d. Setelah mendapatkan pelatihan pembelajaran daring, para guru-guru SD Negeri 091316 Kabupaten Simalungun sebagian besar setuju bahwa Google Classroom ini sangat sederhana sehingga para guru setuju bahwa Google Classroom User Friendly, dalam arti tidak membuat bingung, dan mudah diakses siapapun, baik guru maupun peserta didik. Setelah pelatihan berlangsung para guru-guru SD Negeri 091316 Kabupaten Simalungun diharapkan dapat menggunakan Google Classroom dengan baik. Untuk mempelajari Google Classroom tidak membutuhkan waktu yang lama dalam mempelajari dan mempraktekkannya.

\section{SIMPULAN}

Pelatihan pembelajaran daring yang ditujukan bagi guru-guru SD Negeri 091316 Kabupaten Simalungun sungguh membantu karena dengan pengenalan media-media yang diperkenalkan oleh para narasumber merupakan media yang baru dan masih terasa asing bagi para guru-guru SD Negeri 091316 Kabupaten Simalungun ini. Hal ini tentu memberikan inovasi baru bagi para guru guru-guru SD Negeri 091316 Kabupaten Simalungun untuk merangkai proses pembelajaran daring yang lebih efektif dan lebih inovatif. Tidak hanya itu setelah mendapatkan pelatihan pembelajaran daring, para guru juga menambah keterampilan dalam menggunakan berbagai aplikasi serta tools yang dapat mendukung proses pembelajaran secara daring. Dengan adanya pelatihan pembelajaran daring ini juga telah membuka mind set para guru-guru SD Negeri 091316 Kabupaten Simalungun bahwa proses pembelajaran daring yang dianggap sulit ini ternyata mudah untuk dirancang. Hal ini terjadi karena pada pelatihan pembelajaran daring ini berlangsung, para narasumber tidak hanya menyampaikan secara teoritis saja tetapi ditambah juga dengan praktek langsung.

\section{UCAPAN TERIMA KASIH}

Terlaksananya program kegiatan tri-dharma perguruan tinggi melalui kegiatan pelatihan penggunaan google classroom sebagai media pembelajaran daring pada guru-guru SD Negeri 09316 Kabupaten Simalungun ini adalah berkat kerjasama yang baik antar tim dengan pihak dinas pendidikan. Pada kesempatan ini para dosen pengabdi menyampaikan rasa hormat dan terimakasih atas kerjasama yang baik terkhusus bagi guru-guru SD Negeri 09136 yang telah bersedia mengikuti pelatihan ini, juga kepada bapak kepala dinas pendidikan kabupaten simalungun yang memberikan waktu dan fasilitas kepada para dosen universitas HKBP Nommensen. Tak luput juga kami menyampaikan terimakasih kepada bapak rektor universitas HKBP Nommensen Medan dan Universitas HKBP Nommensen Pematangsiantar dan juga ibu dekan FKIP atas dukungan kerjasama sehingga kegiatan ini dapat berjalan dengan baik. Semoga kegiatan ini dapat lebih meningkatkan mutu dan kualitas para dosen dalam melaksanakan dan mengapresiasikan kompetensi keprofesionalitasan di masa yang akan datang.

\section{DAFTAR PUSTAKA}

Fitra dan Lestari. (2017) Pembelajaran Daring dan Luring: Pengertian, Ciri-ciri, Serta Perbedaannya. 2020. (Online). (https://www.amongguru.com/pembelajaran-daring-dan-luring-pengertian-ciriciri-serta-perbedaannya/).

Nirfayanti. (2019). Pengaruh Media Pembelajaran Google Classroom. Jurnal Penelitian Matematika dan Pendidikan Matematika. 
Permata, A. (2020). Keefektifan Virtual Class dengan Google Classroom dalam Pembelajaran Fisika Dimasa Pandemi Covid-19. JIPFRI (Jurnal Inovasi Pendidikan Fisika dan Riset Ilmiah).

Sabran. (2019). Keefektifan Google Classroom sebagai media pembelajaran. Prosiding Seminar Nasional Lembaga Penelitian Universitas Negeri Makassar.

Tamba. (2012). Media Pembelajaran. (Online). (https://pakdosen.pengajar.co.id/media- pembelajaranadalah/). 